TAPROBANICA, ISSN 1800-427X. October, 2011. Vol. 03, No. 02: pp. 77-85.

(C) Taprobanica Private Limited, Jl. Kuricang 18 Gd.9 No.47, Ciputat 15412, Tangerang, Indonesia.

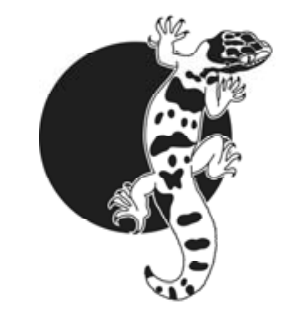

\title{
A NEW SPECIES OF Dendrelaphis (SERPENTES: COLUBRIDAE) FROM THE WESTERN GHATS - INDIA
}

\section{Gernot Vogel ${ }^{1}$ and Johan Van Rooijen ${ }^{2}$}

\author{
${ }^{1}$ Society for Southeast Asian Herpetology, Im Sand 3, D-69115 Heidelberg, Germany \\ E-mail: gernot.vogel@t-online.de \\ ${ }^{2}$ Netherlands Centre for Biodiversity Naturalis (section ZMA), University of Amsterdam, P.O. Box 94766,1090 GT \\ Amsterdam, The Netherlands \\ E-mail: j1.van.rooijen@hetnet.nl
}

\begin{abstract}
A new species of the colubrid genus Dendrelaphis Boulenger 1890 is described from the Western Ghats, India. Dendrelaphis girii sp. nov. resembles Dendrelaphis bifrenalis (Boulenger, 1890) which inhabits Sri Lanka. It differs from the latter predominantly in the absence of a ventrolateral stripe, the much narrower and shorter postocular stripe and the broader snout. The description of $D$. girii sp. nov. underscores the notion that Sri Lanka and the Western Ghats are faunally more distinct than previously thought.
\end{abstract}

Key Words: Dendrelaphis girii sp. nov., Dendrelaphis bifrenalis, taxonomy, reptilia, Sri Lanka

\section{Introduction}

The colubrid snakes of the genus Dendrelaphis Boulenger, 1890 are widely distributed, ranging from Pakistan in the West to the northern and eastern coast of Australia in the East and South and to southern China in the North (Ziegler \& Vogel, 1999). Members of the genus Dendrelaphis are slender, diurnal species that are predominantly arboreal and feed mainly on lizards and amphibians. In 1858, Günther recorded a specimen of the genus Dendrelaphis with two loreal shields. It originated from Sri Lanka. He regarded it as a variety of Dendrophis picta (var. C.) (Gmelin, 1789) but pointed out that, in addition to the double loreal shield, the muzzle is elongate in comparison to Dendrelaphis pictus. Boulenger later described the form represented by Günther's specimen as Dendrophis bifrenalis (1890) on the basis of three syntypes. Four years later he elaborated on his initial description on the basis of the same three specimens (Boulenger, 1894). At some point, this species has again been regarded as a subspecies of Dendrelaphis pictus (Meise \& Henning, 1932; Mertens, 1934).

Ferguson (1895) was the first to record Dendrophis bifrenalis from India and stated that it is not 
uncommon in Trevandrum (today Thiruvananthapuram, Kerala). Subsequently, Wall (1921) confirmed the occurrence of this species in India, namely in Trevandrum and in Travancore (today a part of Kerala). Subsequent works (Smith, 1943; Mahendra, 1984; Sharma, 2007) have not presented new locality records. However, Whitaker \& Captain (2004) doubted the occurrence of this species in India, assuming it to be a Sri Lankan endemic. Thus, despite the fact that Ferguson considered this species to be common, it has been recorded only sparsely. Indeed, no Indian specimen could be located by the authors during investigations in the majority of collections in Europe and several collections in the United States.

Recent species descriptions and revalidations suggest that levels of endemism harboured by Sri Lanka as well as the Western Ghats may be substantially higher than currently known (e.g. Mukherjee \& Bhupathy, 2007; Van Rooijen \& Vogel, 2008; 2009; Vogel \& Van Rooijen, 2011a). This notion, as well as some observed differences in coloration between the Sri Lankan and Indian sister populations of Dendrelaphis bifrenalis, incited this study into the population systematics of this species.

\section{Materials and Methods}

Nineteen museum specimens were examined. This sample represented 13 specimens from Sri Lanka and 6 specimens from the Indian subcontinent. For each examined specimen, 21 characters including aspects of colour pattern, body proportions and scalation were recorded (Table 1). Eye-diameter and distance eye-nostril were measured with a slide calliper to the nearest $0.1 \mathrm{~mm}$. These measurements were made on the left and right side and were subsequently averaged. Snout-vent length and taillength were measured by marking the length on a piece of string and subsequently measuring the position of the mark to the nearest $0.5 \mathrm{~cm}$. Snoutvent length was measured to the posterior margin of the anal plate. The number of ventrals was counted following Dowling (1951). Subcaudals were counted on one side, the terminal scute was excluded. The first sublabial was defined as the scale that starts between the posterior chin shield and the infralabials and that borders the infralabials (see Peters, 1964, fig. 7; Lillywhite, 2008). The last infralabial was defined as the infralabial still covered completely by the last supralabial. The posterior most temporal scales were defined as the scales of which more than half of the area lies in front of an imaginary line that runs from the apex of the last supralabial to the posterolateral corner of the parietal.

Characters were analyzed univariately using either $\chi^{2}$ (stripe2) or ANCOVA (all others). Characters exhibiting significant or near-significant differences $(\mathrm{P}<0.1)$ between the populations were included in a Principal Components Analysis (PCA, e.g. Cramer, 2003). For PCA, morphometric variables were adjusted to a common SVL of $50.5 \mathrm{~cm}$ to correct for potential ontogenetic variation between the samples of the species (e.g. Thorpe, 1975, 1983; How et al., 1996; Turan, 1999). The following allometric equation was applied: $X_{\text {adj }}=X-\beta(S V L$ $\mathrm{SVL}_{\text {mean }}$ ) where $X_{\text {adj }}$ is the adjusted value of the morphometric variable; $\mathrm{X}$ is the original value; SVL is the snout-vent length; $\mathrm{SVL}_{\text {mean }}$ is the overall mean snout-vent length; $\beta$ is the coefficient of the linear regression of $X$ against SVL. All statistical analyses were carried out with the software SPSS (2006; SPSS for Windows. Release 14.0.2. Chicago: SPSS Inc.).

Museum abbreviations: BMNH: The Natural History Museum, London, UK; BNHS: Bombay Natural History Society, Mumbai, India; FMNH: Field Museum of Natural History, Chicago, USA; MHNG: Muséum d'histoire naturelle, Geneve, Switzerland; NMW: Naturhistorisches Museum Wien, Austria; SMF: NaturMuseum und Forschungs-Institut Senckenberg, Frankfurt-am-Main, Germany; USNM: United States National Museum, Washington, USA.

\section{Results}

Statistical analyses: Figure 1 shows the results of a PCA based on the characters VENT, SUBC, TAIL, INFR, TEMP, ATEMP, WSNT, STRIPE1, STRIPE2 and NECK. A clear separation of the two sister populations is in evidence.

Table 2 gives descriptive statistics as well as significance-levels of the differences. The most important differences are the lower number of gular scales, the broader snout, the narrower postocular stripe and the rudimentary ventrolateral stripe in $D$. girii sp. nov.

Taxonomic evaluation: Evidently, the two sister populations differ in several aspects of their morphology and coloration. In addition, the two populations are reproductively isolated due to an extrinsic geographic barrier (the Indian Ocean). Therefore, the two populations are considered to represent separately evolving lineages, and therefore species, in accordance with the general lineage species concept (De Queiroz, 1998, 2007) 


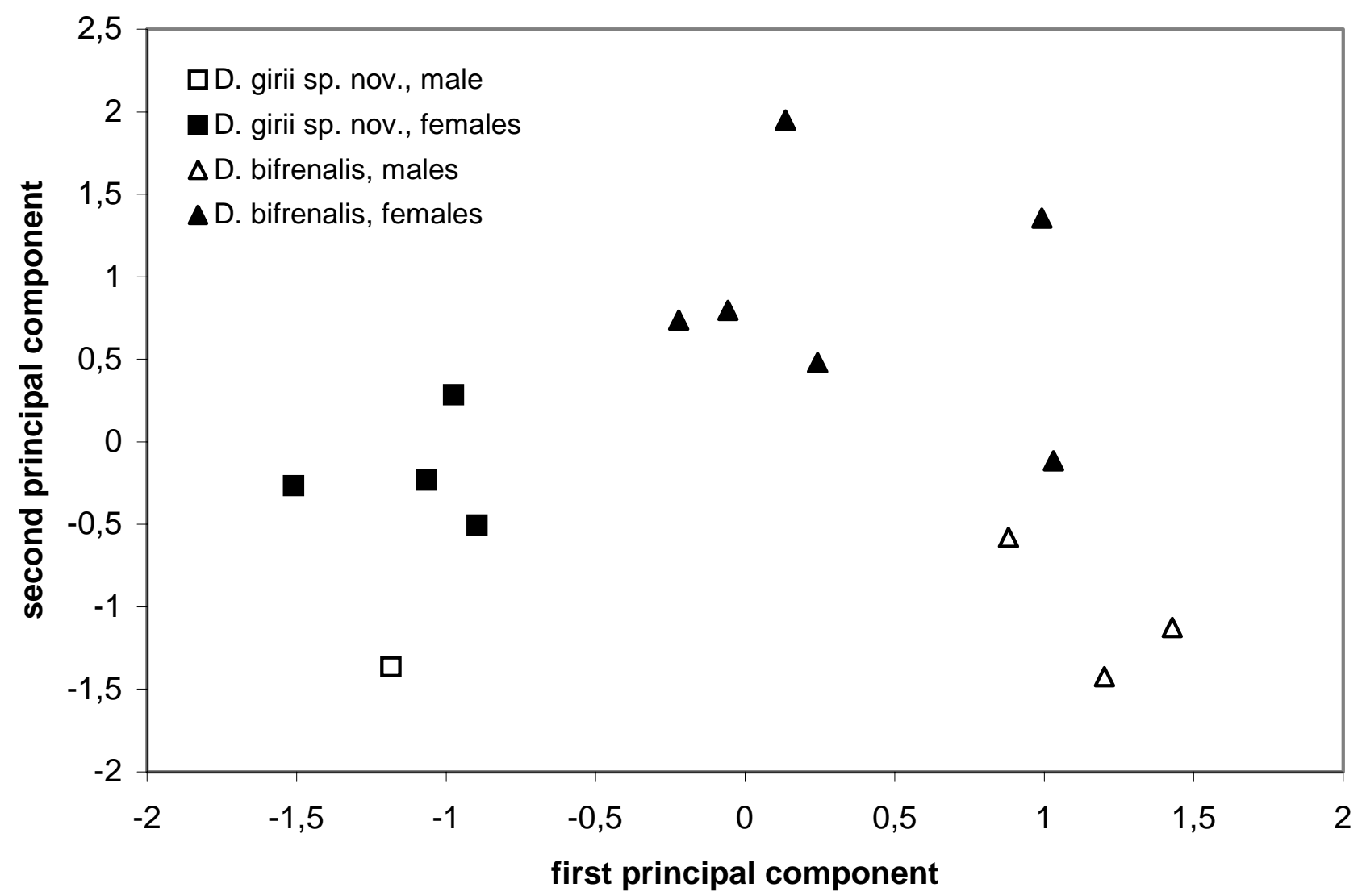

Fig. 1: Ordination of Dendrelaphis girii spec. nov and D. bifrenalis along the first two principal components, based on a PCA of the characters VENT, SUBC, TAIL, INFR, TEMP, ATEMP, WSNT, STRIPE1, STRIPE2 and NECK

Table 1: List of morphometric, meristic and coloration characters used in this study and their abbreviations

\begin{tabular}{ll}
\hline Abbreviation & Character \\
\hline SVLphometrics & \\
TAIL & Snout-vent length \\
HL & Tail-length \\
EYED & Head-length \\
EYEN & Horizontal diameter of the eye \\
WSNT & Distance from centre of the eye to posterior border of the nostril \\
Scalation & Width of the snout \\
VENT & Number of ventrals \\
SUBC & Number of subcaudals \\
DOR1 & Number of dorsal scale rows at 1 head-length behind the head \\
DOR2 & Number of dorsal scale rows at the position of the middle ventral \\
DOR3 & Number of dorsal scale rows at 1 head-length before the tail \\
TEMP & Number of temporals (L+R) \\
SL1 & Number of supralabials (L+R) \\
SL2 & Number of supralabials touching the eyes (L+R) \\
INFR & Number of infralabials (L+R) \\
SUBL & Number of infralabials touched by the first sublabial (L+R) \\
GUL & Number of gulars \\
LOR & Number of loreals (L+R) \\
POC & Number of postoculars (L+R) \\
VERT & Vertebral scales not enlarged (0), enlarged (1) \\
Coloration & \\
Stripe1 & Percentage of temporal region covered by postocular stripe \\
Stripe2 & Light ventrolateral stripe present (1), absent/rudimentary (0) \\
Neck & Black oblique bars on the neck (yes: $1 ;$ no: 0) \\
\hline
\end{tabular}


Table 2: Morphological and coloration characters of Dendrelaphis girii spec. nov and D. bifrenalis. Values of snoutwidth are SVL-adjusted.

\begin{tabular}{lccr}
\hline & D. girii sp. nov. & D. bifrenalis & Significance P \\
\hline relative tail-length & $0.37[0.36-0.37]$ & $0.38[0.37-0.39]$ & 0.02 \\
subcaudals & $144[140-147]$ & $148[141-158]$ & 0.07 \\
ventrals & $170[166-173]$ & $164[156-172]$ & 0.02 \\
infralabials & $20[19-20]$ & $20[19-23]$ & 0.09 \\
temporals & $16[6-18]$ & $12[6-15]$ & 0.03 \\
anterior temporals & $2[1-3]$ & $1.5[1-2]$ & 0.09 \\
snout width & $4.5 \mathrm{~mm}[4.0-4.6]$ & $3.2 \mathrm{~mm}[2.6-3.5]$ & 0.0002 \\
percentage of temporal region covered by postocular stripe & $17 \%[10-25]$ & $60 \%[40-80]$ & 0.0001 \\
clear ventrolateral line present & $0 \%$ & $100 \%$ & 0.002 \\
black bars on the neck & $0 \%$ & $67 \%$ & 0.007 \\
\hline
\end{tabular}

Dendrelaphis girii sp. nov.

Dendrophis bifrenalis: FERGUSON, 1895, WALL, 1921

Ahaetulla bifrenalis: SMITH, 1943

Dendrelaphis pictus bifrenalis: MEISE \& HENNING, 1932, MERTENS, 1934

Dendrelaphis bifrenalis: MAHENDRA, 1984, De Silva, 1980, SHARMA, 2007, WELCH, 1988.

This chresonymy includes only citations based on specimens definitely identified as Dendrelaphis girii sp. nov.

Holotype: BNHS 3494: adult male; Castle Rock, District Belgaum, Karnataka, India; Coll. Sameer Kehimkar \& Varad Giri; Date. 30.IX.2004

Paratypes (5 specimens): (1) BNHS 3495: subadult female; near Keri Village, South Goa, Karnataka, India; 25.V.2003 (2) BNHS 3273: adult female; Khandige Estate, Sirumalai Hills, Tamil Nadu, India; unknown (3) BNHS 3493: adult female; Amboli, District Sindhudurg, Maharashtra, India; 8.VII.2008 (4) BNHS 3491: sex unknown; Amboli, District Sindhudurg, Maharashtra, India; 20.VI.2005 (5) BNHS 3423: adult female; from near Bhimashankar, Pune District, Maharashtra, India; unknown. Coll. the same as holotype.

Diagnosis: A species of Dendrelaphis characterized by the combination of: 1) two loreal scales on each side of the head; 2) 15 dorsal scale rows at midbody; 3) enlarged vertebral scales; 4) 166-173 ventrals; 5) 140-147 subcaudals; 6) 8-9 supralabials, 2 supralabials border the eye; 7) 6-8 temporal scales; 8) a long sublabial that touches 2-5 infralabials; 9) 1-3 gular rows; 10) a divided anal shield; 11) relative tail-length $0.36-0.37$; 12) a black postocular stripe that covers less than a quarter of the temporal region and that barely extends onto the neck; 13) an absent or rudimentarily present pale ventrolateral line.
Etymology: We want to dedicate this species to Varad Giri, the curator of the herpetological collection of the Bombay Natural History Society. He contributed enormously to the knowledge of the Indian reptiles by his own research and by making the BNHS collection easily available for all kind of researchers.

Description of the holotype (Fig. 2 \& 3): Adult male; dissected; body very slender; snout-vent length $65.3 \mathrm{~cm}$; tail-length $37.3 \mathrm{~cm}$; relative tail length 0.36; head distinct from neck; head-length $23.1 \mathrm{~mm}$; snout width $5.5 \mathrm{~mm}$; pupil round; eyediameter $4.45 \mathrm{~mm}$ (left/right averaged); distance eye-nostril $4.85 \mathrm{~mm}$ (left/right averaged); 169 ventrals; 147 subcaudals; dorsal scales in 15-15-11 rows; 9 supralabials, 5th and 6th border the eye; 9/10 infralabials, infralabials $1-5$ touch the first chinshield, infralabials 5 and 6 touch the second chinshield; 1 preocular; 2 postoculars; 2 loreals, anterior one larger than posterior one and more elongate; temporal formula 2:1:2:2 (L), 2:2:1:2 (R); first sublabial touches infralabials 6 through 9; vertebrals moderately enlarged, with straight posterior margin, width of the vertebral scale at the position of the middle ventral scale $2.8 \mathrm{~mm}$; anal divided; parietal scales bordered posteriorly by 4 scales (not being temporal scales). Ground colour of body and tail bluish-grey mixed with brown (depending on the upper layer of the skin, which is partly damaged), the upper head brown (preservation artefact); supralabials whitish; 7th 9th supralabials with dark dorsal margins, the preocular dark on its ventral part; a black postocular stripe starts behind the eye, covers only a small part of the temporal region, and extends to the upper jaw with a few spots behind the ankle of the jaw; no ventrolateral line present, belly and underside of the tail uniform whitish. 

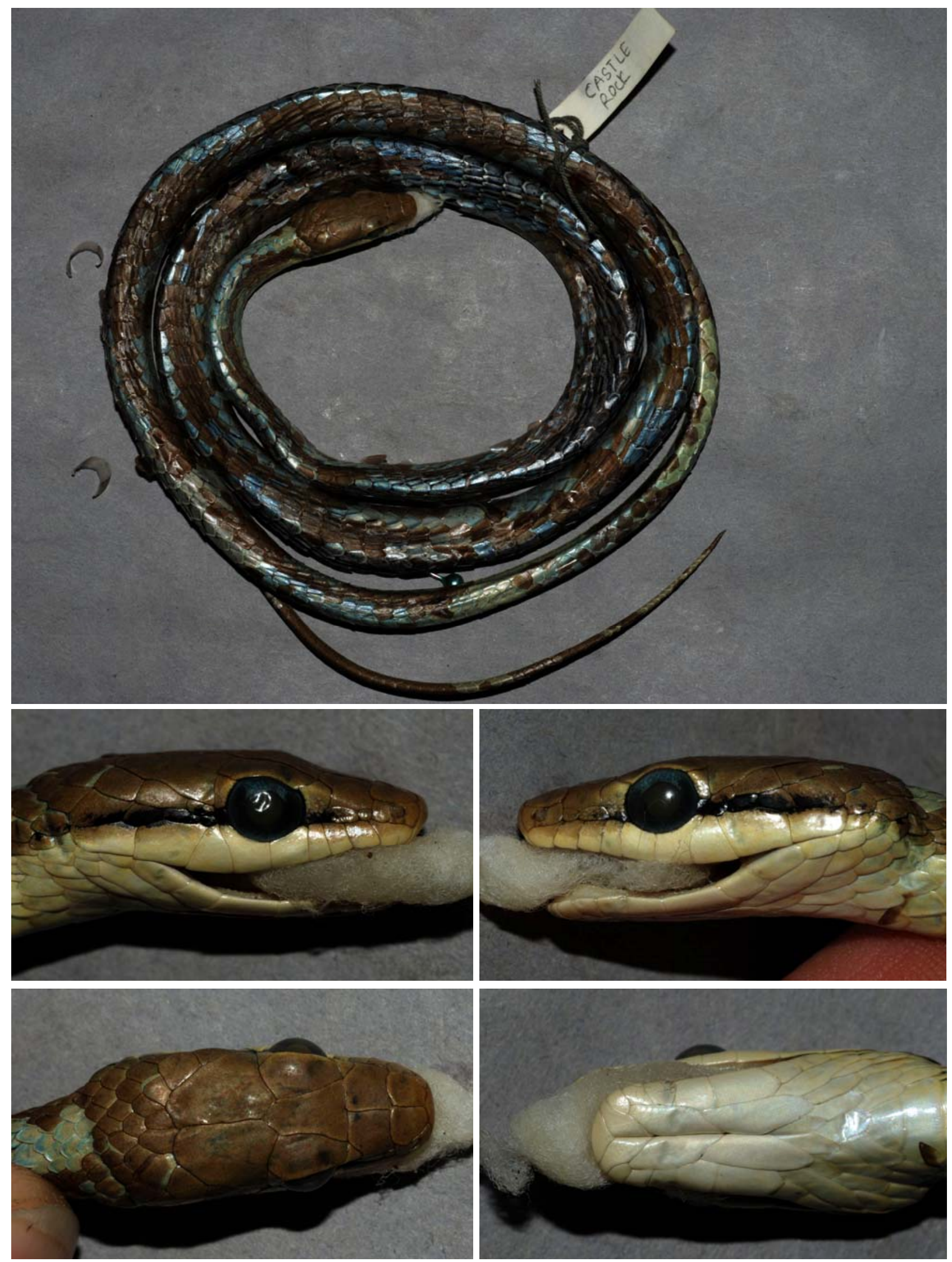

Fig. 2: BNHS 3494: adult male; Castle Rock, Belgaum District, Karnataka State, India; Holotype of Dendrelaphis girii sp. nov. 


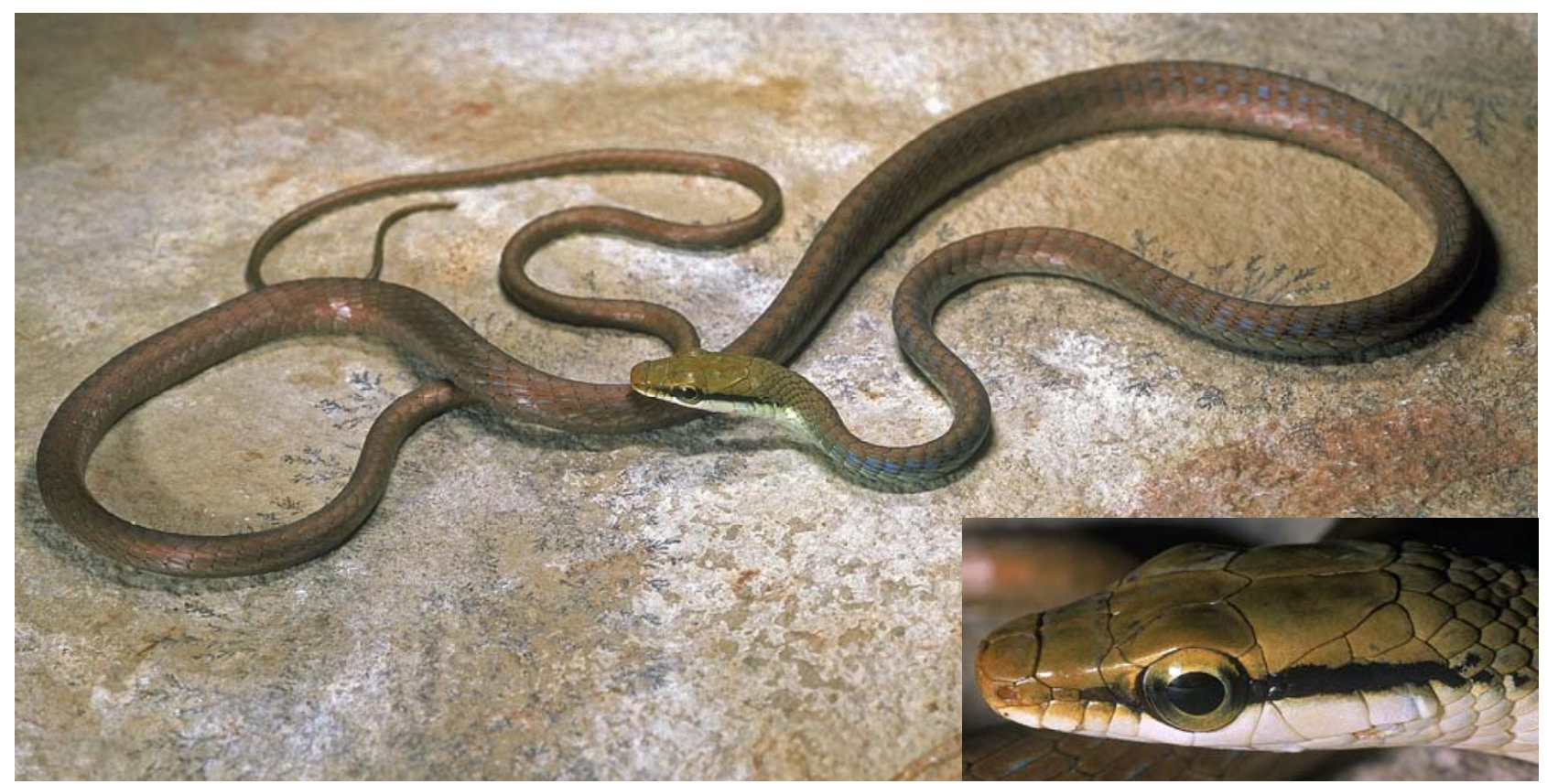

Fig. 3: Dendrelaphis girii (in life, specimen was not preserved); close-up of the head enlarged; Photos: Ashok Captain

Description of the paratypes: A summary of morphological and coloration data of the paratypes is given in Table 3. Other important characters agree with features of the holotype.

Table 3: Morphological and coloration characters of the types of Dendrelaphis girii sp. nov.

\begin{tabular}{|c|c|c|c|c|c|c|}
\hline Collection number BNHS & 3494 & 3423 & 3495 & 3273 & 3493 & 3491 \\
\hline status & Holotype & Paratype & Paratype & Paratype & Paratype & Paratype \\
\hline Sex & $\mathrm{m}$ & f & $\mathrm{f}$ & $\mathrm{f}$ & $\mathrm{f}$ & $?$ \\
\hline Snout-vent length (cm) & 65.3 & 57.3 & 46.5 & 51.5 & 74.3 & 64.7 \\
\hline Tail-length $(\mathrm{cm})$ & 37.3 & 33.4 & 27.1 & 29.8 & - & 37.5 \\
\hline Head-length (mm) & 23.1 & 20.7 & 17.6 & 18.9 & 26.3 & 22.9 \\
\hline Eye-diameter (mm) & $4.4 / 4.3$ & $4.0 / 4.0$ & $3.6 / 3.8$ & $3.2 / 3.5$ & $4.7 / 4.9$ & $4.4 / 4.4$ \\
\hline Eye-nostril distance (mm) & $5.0 / 4.7$ & $4.5 / 4.8$ & $3.8 / 4.1$ & $4.0 / 4.1$ & $6.1 / 5.6$ & $5.3 / 5.4$ \\
\hline Snout-width (mm) & 5.5 & 5.3 & 3.9 & 4.7 & 6.9 & - \\
\hline Ventrals & 169 & 166 & 167 & 173 & 171 & 170 \\
\hline Subcaudals & 147 & 140 & 142 & 145 & inc & 144 \\
\hline Dorsal formula & $15-15-11$ & $16-15-11$ & $15-15-11$ & $15-15-11$ & 15-15-11 & $17-15-11$ \\
\hline Temporal formula & $2122 / 2212$ & $2222 / 22212$ & $2221 / 2122$ & $12 / 12$ & $3221 / 22231$ & $3222 / 3132$ \\
\hline Supralabials & $9 / 9$ & $9 / 9$ & $9 / 8$ & 9/9 & $9 / 9$ & $7 / 8$ \\
\hline Supralabials touching the eye & $5,6 / 5,6$ & $5,6 / 5,6$ & $5,6 / 5,6$ & $5,6 / 5,6$ & $5,6 / 5,6$ & $4 / 4,5$ \\
\hline Infralabials & $9 / 10$ & $10 / 10$ & $10 / 10$ & $10 / 10$ & $9 / 10$ & $10 / 10$ \\
\hline $\begin{array}{l}\text { Infralabials touched by first } \\
\text { sublabial }\end{array}$ & $6-9 / 6-9$ & $6-8 / 7-9$ & $6-9 / 6-9$ & $6-10 / 6-9$ & $6-8 / 6-8$ & $6,7 / 6,7$ \\
\hline Loreals & $2 / 2$ & $2 / 2$ & $2 / 2$ & $2 / 2$ & $2 / 2$ & $2 / 2$ \\
\hline Postoculars & $2 / 2$ & $2 / 2$ & $2 / 2$ & $2 / 2$ & $3 / 3$ & $2 / 2$ \\
\hline Vertebrals enlarged & yes & yes & yes & yes & yes & yes \\
\hline Anal shield divided & yes & yes & yes & yes & yes & yes \\
\hline $\begin{array}{l}\text { Light ventrolateral stripe } \\
\text { absent or rudimentary }\end{array}$ & yes & yes & yes & yes & yes & yes \\
\hline $\begin{array}{l}\text { Percentage of temporal } \\
\text { region covered by postocular } \\
\text { stripe }\end{array}$ & 10 & 20 & 25 & 20 & 10 & 15 \\
\hline S & $\begin{array}{l}\text { Castlerock, } \\
\text { Belgaum Dist., } \\
\text { Karnataka }\end{array}$ & $\begin{array}{c}\text { Near } \\
\text { Bhimashankar, } \\
\text { Pune Dist., } \\
\text { Maharashtra }\end{array}$ & $\begin{array}{l}\text { Near Keri } \\
\text { Village, } \\
\text { South Goa, } \\
\text { Karnataka }\end{array}$ & $\begin{array}{c}\text { Khandige } \\
\text { Estate, } \\
\text { Sirumalai } \\
\text { Hills, } \\
\text { Tamil Nadu } \\
\end{array}$ & $\begin{array}{c}\text { Amboli, } \\
\text { Sindhudurg } \\
\text { Dist., } \\
\text { Maharashtra }\end{array}$ & $\begin{array}{c}\text { Amboli, } \\
\text { Sindhudurg } \\
\text { Dist., } \\
\text { Maharashtra }\end{array}$ \\
\hline
\end{tabular}


Range: Dendrelaphis girii sp. nov. inhabits the Western Ghats, South India. It was found in the states of Karnataka, Tamil Nadu and Maharashtra.

Comparison with other species: Due to their double loreal shield, D. girii sp. nov. and D. bifrenalis occupy a unique position within the genus. A congeneric species with a double loreal shield has been described in the past, namely Dendrelaphis biloreatus (Wall, 1908). However, the presence of a double loreal in D. biloreatus appears to be based either on an anomalous specimen or on a misjudgement (Vogel \& Van Rooijen, 2011b). Furthermore, $D$. biloreatus differs from $D$. girii sp. nov. and $D$. bifrenalis in its number of dorsal scale rows (13) and its number of ventral scales (190199).

There are several differences between Dendrelaphis girii sp. nov and $D$. bifrenalis. The most obvious one is the light ventrolateral line, which is present in $D$. bifrenalis and missing or very faint in Dendrelaphis girii sp. nov. (see Fig. 3, 4).

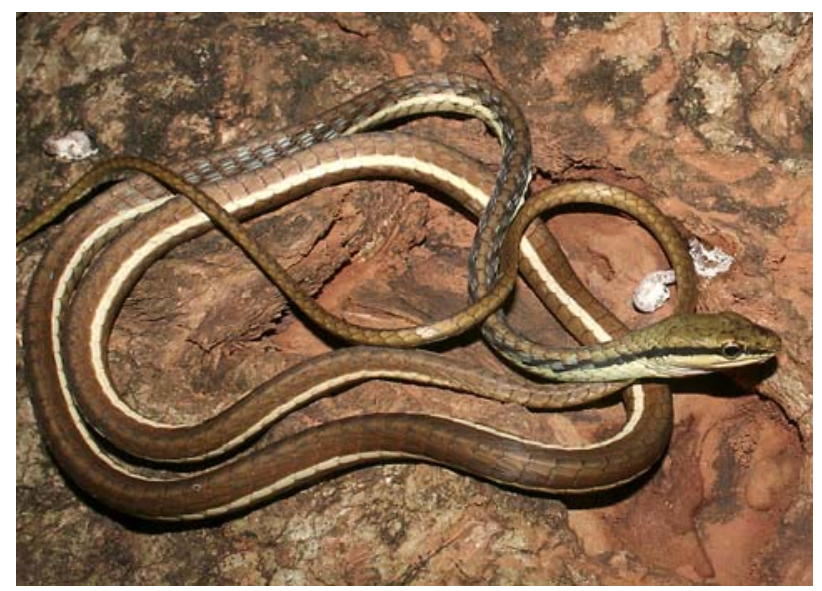

Fig. 4: Dendrelaphis bifrenalis, live specimen from Kandy - Sri Lanka. Notice the conspicuous white ventrolateral stripe; Photo: Ruchira Somaweera

The postocular stripe is much broader in $D$. bifrenalis. In $D$. bifrenalis there are black oblique bars in the neck region of some, but not all specimens ( 8 specimens out of 12 in our data) (see Fig. 3-5). This pattern is not sex related. It is absent in D. girii sp. nov. For Dendrelaphis girii sp. nov. we had only 1 male, so it is not possible to compare the sexual dimorphism in this character. The snout of Dendrelaphis girii sp. nov. is much broader than that of $D$. bifrenalis. Dendrelaphis girii sp. nov. has, on average, fewer subcaudals and more ventrals than $D$. bifrenalis, but the ranges broadly overlap.

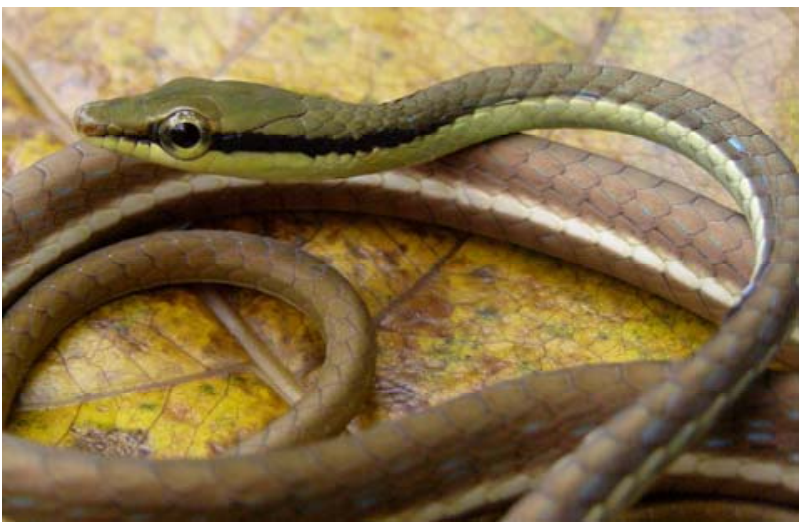

Fig. 5: Dendrelaphis bifrenalis, live specimen from Kiriella (near Ingiriya); alt. $210 \mathrm{~m}$ a.s.l. - Sri Lanka; Photo: Suranjan Karunarathna

\section{Discussion}

Dendrelaphis girii sp. nov. is undoubtedly a sister species of $D$. bifrenalis. Both species exhibit a double loreal shield, a unique character within the genus, and are phenetically very similar in other aspects of morphology as well. Possibly, the common ancestor of both species dispersed across the land bridge between India and Sri Lanka that came into existence due to Pleistocene lowering of sea levels (e.g. Voris, 2000; Pethiyagoda, 2005). Subsequent isolation would have provided the opportunity for independent evolution of the sister populations.

The Western Ghats and Sri Lanka together have been designated as one of the biodiversity hotspots of the world (Mittermeier et al., 2005) and are known to host a high level of endemism among reptiles (e.g. Das, 1996; Ishwar et al., 2001; Mittermeier et al., 2005; Gunawardene et al., 2007). Recent species descriptions suggest that biodiversity as well as the level of endemism harboured by this area may be substantially higher than currently known (e.g. Pethiyagoda, 2005; Wickramasinghe et al., 2007; Mukherjee \& Bhupathy, 2007). This notion is underscored by recent insights into the taxonomy of the genus Dendrelaphis: one Sri Lankan endemic, D. schokari Kuhl, 1820 was resurrected from synonymy (Van Rooijen \& Vogel, 2008), one South Indian species, D. chairecacos Boie, 1827, was resurrected from synonymy (Van Rooijen \& Vogel, 2009), and two new species, D. ashoki Vogel \& Van Rooijen, 2011a and D. girii sp. nov. (this report) have now been described from the Western Ghats. Furthermore, these results add to the notion that the faunas of Sri Lanka and the Western Ghats are more distinct than previously recognized (e.g. Bossuyt et al., 2004). 


\section{Specimens examined}

Dendrelaphis girii sp. nov.:

BNHS 3423, Near Bhimashankar, District Pune, Maharashtra, coll. S. Kehimkar; BNHS 3495, Near Keri Village, South Goa, Karnataka, coll. S. Korajkar and team; BNHS 3273, Khandige Estate, Sirumalai Hills, Tamil Nadu, coll. S.P. Vijaykumar; BNHS 3494, Castlerock, District Belgaum, Karnataka, coll. V. Giri and S. Kehimkar; BNHS 3493, Amboli, District Sindhudurg, Maharashtra, coll. V. Giri and Team; BNHS 3491, Amboli, District Sindhudurg, Maharashtra; coll. V. Giri and S. Kehimkar

\section{Dendrelaphis bifrenalis}

MHNG 1553.9, Inde; MHNG 743.37b, 782.75, 743.36 "Ceylon"; NMW 23724, Kandy, Sri Lanka; SMF 25483 Polonaruwa, Ceylon; FMNH 142366, Ceylon; BM 1946.1.6., 1946. 1.10.194, 1946.1.10.20, Syntypes, BM 94.9.11.20, Ceylon; BM 1905.3.25.98, Pundaluoya, 4000 feet, Ceylon; USNM 267765, Labugama, Sri Lanka. A fourth specimen marked as type in the collection of the British Museum (BM 94.9.11.20), should not be regarded as part of the type series.

\section{Acknowledgements}

We would like to thank Suranjan Karunarathna (Sri Lanka), Ruchira Somaweera (Sri Lanka) and Ashok Captain (India) for their valuable pictures of these uncommon species. We are grateful to Varad Giri (BNHS) and two unknown reviewers for their critical reading of this manuscript and their constructive comments that greatly improved content and language of this paper. We thank Varad Giri and Asad Rahmahi (BNHS), Colin J. McCarthy and Patrick Campbell (BMNH), Gunther Köhler and Linda Acker (SMF), George Zug and Ron McDiarmid (USNM), Franz Tiedemann and Richard Gemel (NMW), Andreas Schmitz (MHNG), Alan Resetar (FMNH), for their assistance in sending us or letting us examine preserved specimens.

\section{Literature Cited}

Bossuyt, F., M. Meegaskumbura, N. Beenaerts, D. J. Gower, R. Pethiyagoda, K. Roelants, A. Mannaert, M. Wilkinson, M. M. Bahir, K. Manamendra-Arachchi, P. K. L. Ng, C. J. Schneider, O. V. Oommen and M. C. Milinkovitch, 2004. Local endemism within the Western Ghats - Sri Lanka Biodiversity Hotspot. Science, 306: 479.
Boulenger, G. A., 1890. The Fauna of British India, Including Ceylon and Burma.Reptilia and Batrachia. Taylor \& Francis, London: xviii+541.

Boulenger, G. A., 1894. Catalogue of the Snakes in the British Museum (Natural History). Volume II., Containing the Conclusion of the Colubridae Aglyphae. Taylor \& Francis, London: xi+382.

Cramer, D., 2003. Advanced quantitative data analysis. Open University Press, Philadelphia.

Das, I., 1996. Biogeography of the Reptiles of South Asia. Krieger Publishing Company, Malabar, Florida, USA: vii+87+36pls.

De Queiroz, K., 1998. The general lineage concept of species, species criteria, and the process of speciation: A conceptual unification and terminological recommendations. In: Endless Forms: Species and Speciation, Howard D. J., S. H. Berlocher (Eds). Oxford University Press, Oxford: 57-75.

De Queiroz, K., 2007. Species concepts and species delimitation. Systematic Biology, 56 (6): 879-886.

De Silva, P. H. D. H., 1980. - Snake fauna of Sri Lanka, with special reference to skull, dentition and venom in snakes. Spolia Zeylanica, 34 (1-2): $\mathrm{xi}+472+67$ pls.

Dowling, H. G., 1951. A proposed standard system of counting ventrals in snakes. British Journal of Herpetology, 1: 97-99.

Ferguson, H. S., 1895. List of snakes taken in Travancore from 1888 to 1895 . Journal of the Bombay Natural History Society, 10: 68-77.

Günther A. C. L. G., 1858. - Catalogue of colubrine snakes in the collection of the British Museum. British Museum of natural History, London: xvi+281.

Gmelin, J. F., 1789. Carola a Linné Systema Naturae. G. E. Beer, Leipzig. 1 (3): 1033-1516.

Gunawardene, N. R., A. E. D. Daniels, I. A. U. N. Gunatilleke, C. V. S. Gunatilleke, P. V. Karunakaran, K. G. Nayak, S. Prasad, P. Puyravaud, B. R. Ramesh, K. A. Subramanian and G. Vasanthy, 2007. A brief overview of the Western Ghats- Sri Lanka biodiversity hotspot. Current Science, 93: 1567-1572.

How, R. A., L. H. Schmitt and Maharadatunkamsi, 1996. Geographical variation in the genus Dendrelaphis (Serpentes: Colubridae) within the islands of south-eastern Indonesia. Journal of Zoology, 238: 351-363. 
Ishwar, N. M., R. Chellam and A. Kumar, 2001. Distribution of forest floor reptiles in the rainforest of Kalakad-Mundanthurai Tiger Reserve, South India. Current Science, 80(3): 413-418.

Lillywhite, H. B., 2008. Dictionary of Herpetology. Krieger Publishing Company, Malabar, Florida: 376.

Mahendra, B. C., 1984. Handbook of the snakes of India, Ceylon, Burma, Bangladesh and Pakistan. Annals of Zoology (AGRA), 22 (B): xvi+412.

Meise, W. and W. Henning, 1932. Die Schlangengattung Dendrophis. Zoologischer Anzeiger, 99 (11/12): 273-297.

Wickramasinghe, L. J. M., R. Rodrigo, Nihal Dayawansa and U. L. D. Jayantha, 2007. Two new species of Lankascincus (Squamata: Scincidae) from Sripada Sanctuary (Peak Wilderness), in Sri Lanka. Zootaxa, 1612: 1-24.

Mertens, R., 1934. Die Schlangengattung Dendrelaphis Boulenger in systematischer und zoogeographischer Beziehung. Archiv für Naturgeschichte, Berlin (N. F.), 3(2): 187-204.

Mittermeier, R. A., P. R. Gil, M. Hoffman, J. Pilgrim, T. Brooks, C. G. Mittermeier, J. Lamoreux and G. A. B. da Fonseca, 2005. Hotspots Revisited: Earth's Biologically Richest and Most Endangered Terrestrial Ecoregions. Cemex, Conservation International and Agrupacion Sierra Madre, Monterrey, Mexico: 392.

Mukherjee, D. and S. Bhupathy, 2007. A new species of Wolf Snake (Serpentes: Colubridae: Lycodon) from Anaikatti Hills, Western Ghats, Tamil Nadu, India. Russian Journal of Herpetology, 14: 21-26.

Peters, J. A., 1964. Dictionary of herpetology: a brief and meaningful definition of words and terms used in herpetology. Hafner Publ. Co., New York: 392.

Pethiyagoda, R., 2005. Exploring Sri Lanka's biodiversity. The Raffles Bulletin of Zoology Supplement 12: 1-4.

Sharma, R. C., 2007. The fauna of India and the adjacent countries. Reptilia (Serpentes). Zoological Survey India, Kolkata: 410.

Smith, M. A., 1943. The fauna of British India, Ceylon and Burma. Reptilia and Amphibia. Vol.3 Serpentes. Taylor \& Francis, London: 583.

Thorpe, R. S., 1975. Quantitative handling of characters useful in snake systematics with particular reference to intraspecific variation in the Ringed
Snakes Natrix natrix (L.). Biological Journal of the Linnean Society, 7: 27-43.

Thorpe, R. S., 1983. A biometric study of the effects of growth on the analysis of geographic variation: Tooth number in Green geckos (Reptilia: Phelsuma). Journal of Zoology, London, 201: 13-26.

Turan, C., 1999. A note on the examination of morphometric differentiation among fish populations: the Truss System. Turkish Journal of Zoology, 23: $259-263$

Van Rooijen, J. and G. Vogel, 2008. An investigation into the taxonomy of Dendrelaphis tristis (Daudin, 1803): revalidation of Dipsas schokari (Kuhl, 1820) (Serpentes, Colubridae). Contributions to Zoology, 77 (1): 33-43.

Van Rooijen, J. and G. Vogel, 2009. A multivariate investigation into the population systematics of Dendrelaphis tristis (Daudin, 1803) and Dendrelaphis schokari (Kuhl, 1820): revalidation of Dendrophis chairecacos Boie, 1827 (Serpentes: Colubridae). The Herpetological Journal, 19: 193-200.

Vogel, G. and J. van Rooijen, 2011a. Contributions to a review of the Dendrelaphis pictus (Gmelin, 1789) complex (Serpentes: Colubridae) - 3. The Indian forms, with the description of a new species from the Western Ghats. Journal of Herpetology, 45: 100-110.

Vogel, G. and J. Van Rooijen, 2011b. Description of a new species of the genus Dendrelaphis Boulenger, 1890 from Myanmar (Squamata: Serpentes: Colubridae). Bonn Zoological Bulletin, 60: 17-24.

Voris, H. K., 2000. Maps of Pleistocene sea levels in Southeast Asia: shorelines, river systems and time durations. Journal of Biogeography, 27: 1153-1167.

Wall, F., 1908. Two new snakes from Assam. Journal of the Bombay Natural History Society, 18: 272-274.

Wall, F., 1921. Remarks on the Indian Species of Dendrophis and Dendrelaphis. Records of the Indian Museum, 22: 151-162.

Welch, K. R. G., 1988. Snakes of the Orient: $a$ checklist. Robert E. Krieger Publ. Co, Malabar, Florida: vii+183.

Whitaker, R. and A. Captain, 2004. Snakes of India: A field guide. Draco Books, Chennai, India: 481.

Ziegler, T. and G. Vogel, 1999. On the knowledge and specific status of Dendrelaphis ngansonensis (Bourret, 1935) (Reptilia: Serpentes: Colubridae). Russian Journal of Herpetology, 6: 199-208. 